\title{
PERKEMBANGAN FATWA MUI TENTANG MASALAH ZAKAT
}

\author{
Widi Nopiardo \\ Fakultas Ekonomi dan Bisnis Islam IAIN Batusangkar \\ J1. Jenderal Sudirman No. 137, Lima Kaum Batusangkar \\ e-mail: widinopiardo@iainbatusangkar.ac.id
}

\begin{abstract}
In the management of zakat, of there are parties that require regulations and need fatwa as a reference in the management of zakat. This type of research was normative research using qualitative analysis. The type of data in this research were secondary data which were taken from relevant books, internet media, documents, and previous research which studied about the farwa of about zakat. The data were analyzed by using qualitative data with method of analysis and normative study based on existing written sources. The results showed that from 1982 s.d. 2011 there were 10 fatwas discussing rakat that can be presented in detail as follow: 2 fatwas in 1982, 1 fatwa in 1996, 2 fatwas in 2003, 1 fatwa in 2009, and 4 fatwas in 2011.
\end{abstract}

Kata kunci: fatwa, Majelis Ulama Indonesia, zakat

\section{PENDAHULUAN}

$\mathcal{M}$ ajelis Ulama Indonesia (MUI) merupakan wadah musyawarah para ulama, zu'ama, dan cendekiawan muslim. MUI berperan sebagai pengayom bagi seluruh muslim Indonesia. Di samping itu MUI merupakan lembaga paling berkompeten bagi pemecahan dan menjawab setiap masalah sosial keagamaan yang senantiasa timbul dan dihadapi masyarakat.

Salah satu amanah Musyawarah Nasional Majelis Ulama Indonesia (Munas MUI) tahun 2010 adalah sosialisasi hasilhasil fatwa ke masyarakat banyak. Dengan demikian diharapkan dapat dijadikan pedoman dalam kehidupan keagamaan dan kemasyarakatan. Salah satu upaya sosialisasi fatwa MUI ini adalah melalui penerbitan kompilasi fatwa, agar fatwa yang ditetapkan MUI dapat diakses oleh masyarakat secara lebih luas dan dapat dijadikan rujukan dalam kehidupan bermasyarakat, berbangsa, dan bernegara.

Dalam pedoman penetapan fatwa MUI disebutkan bahwa MUI Pusat berwenang mengeluarkan fatwa mengenai permasalahan keagamaan yang bersifat umum dan menyangkut permasalahan umat Islam Indonesia secara nasional dan/ atau masalahmasalah keagamaan yang terjadi di daerah, namun efeknya dapat meluas ke daerah-daerah lain.

Umat Islam Indonesia semestinya menghormati kedudukan dan fungsi MUI serta menjadikan fatwa MUI sebagai rujukan dalam menghadapi persoalan- 
persoalan keagamaan dan kemasyarakatan. Fatwa yang dikeluarkan oleh ulama pada MUI telah banyak, salah satunya adalah fatwa tentang zakat.

Dalam bidang zakat ini juga sudah terdapat sinergi antara ulama dengan pemerintah, pemerintah juga telah mengeluarkan berbagai macam regulasi yaitu Undang-undang No. 38 Tahun 1998 tentang Pengelolaan Zakat dan Undangundang No. 23 Tahun 2011 tentang Pengelolaan Zakat.

Dalam pengelolaan zakat tentu pihak-pihak terkait di samping membutuhkan regulasi juga sangat membutuhkan fatwa sebagai rujukan dalam pengelolaan zakat. Oleh karena itu dalam tulisan ini dikemukakan berbagai fatwa tentang masalah zakat yang telah dikeluarkan oleh MUI Pusat sebagai pedoman pengelolaan zakat, sekaligus sebagai sarana untuk mensosialisasikan fatwa tersebut di tengah umat. Sehubungan dengan pembahasan yang semakin kompleks, agar lebih fokusnya hasil penelitian maka pada tulisan ini dibatasi rentang waktu objek penelitian penulis yaitu fatwa MUI dari tahun 1982 s.d 2011, tahun dimana diundangkannya UU No. 23 tahun 2011 tentang Pengelolaan Zakat.

\section{METODE PENELITIAN}

Jenis penelitian ini adalah penelitian normatif menggunakan analisis kualitatif yakni dengan menjelaskan data-data yang ada dengan kata-kata atau pernyataan bukan dengan angka-angka. Dan menggunakan pendekatan konsep (conceptual approach) tentang urgensi fatwa MUI tentang zakat terhadap pengeloaan zakat di Indonesia melalui penelitian perpustakaan ataupun studi dokumen disebabkan penelitian ini lebih banyak dilakukan terhadap data yang bersifat sekunder

Adapun jenis data dalam penelitian ini adalah data sekunder, yaitu data dari buku-buku, media internet, dokumen, dan penelitian terdahulu yang mengkaji tentang fatwa MUI tentang zakat. Sedangkan teknik pengumpulan data, yaitu dengan menelaah buku-buku, media internet, dokumen, dan penelitian terdahulu. Teknik analisis data, yaitu dengan menggunakan data kualitatif dengan metode analisis dan kajian normatif berdasarkan sumber-sumber tertulis yang ada.

\section{PEMBAHASAN}

\section{Pengertian Fatwa}

Fatwa berasal dari bahasa Arab,فتوى yang artinya nasihat, petuah, jawaban atau pendapat. Adapun yang dimaksud adalah sebuah keputusan atau nasihat resmi yang diambil oleh sebuah lembaga atau perorangan yang diakui otoritasnya, disampaikan oleh seorang mufti atau ulama, sebagai tanggapan atau jawaban terhadap pertanyaan yang diajukan oleh peminta fatwa (mustafti) yang tidak mempunyai keterikatan.

Dari segi terminologi fatwa adalah pendapat atau keputusan dari alim ulama atau ahli hukum Islam. (Sudarsono, 1990: 127)

Dalam Kamus Besar Bahasa Indonesia disebutkan, fatwa adalah jawab (keputusan/pendapat) yang diberikan oleh mufti terhadap suatu masalah atau juga dinamakan dengan petuah. (Depdikbud, 1990: 314) 
Sedangkan dalam ilmu ushul figh, fatwa berarti pendapat yang dikemukakan oleh seorang mujtahid atau fakih sebagai jawaban yang diajukan peminta fatwa dalam satu kasus yang sifatnya tidak mengikat. (Dahlan (Eds), 1999: 326) Pihak yang meminta fatwa tersebut bisa pribadi, lembaga maupun kelompok masyarakat.

Ada juga yang mengartikan fatwa sebagai pendapat mengenai suatu hukum dalam Islam yang merupakan tanggapan atau jawaban terhadap pertanyaan yang diajukan oleh peminta fatwa dan tidak mempunyai daya ikat. (Ensiklopedi Islam, 2001: 6-7)

Fatwa juga dapat disebut dengan $r a^{\prime} y u$. $R a^{\prime} y u$ didefinisikan sebagai pendapat tetang suatu masalah yang tidak diatur oleh Alquran dan Sunnah. $R a^{\prime} y u$ adalah pendapat yang dipertimbangkan dengan matang, yang dicapai sebagai hasil pemikiran yang dalam dan upaya keras individu dengan tujuan menyingkapkan dan mencari pengetahuan tentang suatu subyek yang mungkin hanya menjadi pertanda atau indikasi dari hal lain. (Kamali, 1996: 89)

Tindakan memberi fatwa disebut futya atau ifta, suatu istilah yang merujuk pada profesi pemberi nasihat. Orang yang memberi fatwa disebut mufti atau ulama, sedangkan yang meminta fatwa disebut mustafti. Peminta fatwa bisa perseorangan, lembaga ataupun siapa saja yang membutuhkannya.

Hukum berfatwa adalah fardhu kifayah, kalau ada orang lain yang bisa memberi fatwa selain dirinya. Adapun kalau tidak ada orang lain yang bisa memberi fatwa dan masalah yang difatwakan itu cukup mendesak maka ia pun secara fardhu 'ain wajib memberi fatwa atas pristiwa itu.
Oleh karena fatwa itu menyangkut masalah agama maka tidak sembarang orang bisa menduduki sebagai mufti syarat-syarat yang harus dimiliki oleh seorang mufti antara lain adalah:

1. Fatwanya harus didasarkan kepada kitab-kitab induk yang mutabar agar fatwa yang diberikan itu dapat diterima oleh penerima fatwa.

2. Apabila ia berfatwa berdasarkan qoul seseorang alim, maka ia dapat menunjukan dasar sumber pengambilan fatwanya itu, dengan demikian ia terhindar dari berbuat salah dan bohong.

3. Seorang mufti harus mengerti atau mengetahui berbagai macam pendapat ulama agar tidak terjadi kesalah pahaman antara ia dan penerima fatwanya.

4. Seorang mufti haruslah seorang alim yang memiliki kejujuran. (Zen, 2009: 213)

\section{Kedudukan Fatwa}

Keperluan terhadap fatwa sudah terasa sejak awal perkembangan Islam. Dengan meningkatnya jumlah pemeluk Islam, maka setiap persoalan yang muncul memerlukan jawaban. Untuk menjawab persoalan tersebut diperlukan bantuan dari orang-orang yang kompeten di bidang tersebut. Dalam masalah agama, yang berkompeten untuk itu adalah para mufti atau para mujtahid.

Pada mulanya praktik fatwa yang diberikan secara lepas dan belum ada upaya untuk membukukan isi fatwa ulama-ulama tersebut. Fatwa pertama kali dikumpulkan dan sebuh kitab pada abad ke-12 M. Mazhab Hanafi memiliki sejumlah kitab fatwa seperti az-Zakhirat alBurhaniyah, kumpulan fatwa Burhanuddin 
bin Maza (wafat $570 \mathrm{H} / 1174$ ). Inilah kitab kumpulan fatwa pertama.

Mazhab Maliki memiliki kitab kumpulan fatwa bertajuk al-Mi'yar alMagrib yang berisi fatwa-fatwa alWasyarisi (wafat 914 H/1508 M). Mazhab Hanbali juga memiliki sejumlah kitab fatwa, yang paling terkenal adalah Majmu al-Fatawa.

Di Indonesia juga ada sejumlah buku kumpulan fatwa, seperti Tanya Jawab Agama dan Kata Berjawab yang diterbitkan Majelis Tarjih PP Muhammadiyah, selain itu ada juga Himpunan Fatwa Majelis Ulama Indonesia, serta Solusi Problematika Aktual Hukum Islam Keputusan Muktamar Munas dan Konbes Nahdlatul Ulama.

Berkaitan dengan kedudukan fatwa dalam kehidupan umat Islam, fatwa ini juga menegaskan bahwa fatwa memang tidak mengikat secara hukum, akan tetapi, ia bersifat mengikat secara agama, sehingga tidak ada peluang bagi seorang muslim untuk menentangnya bila fatwa itu didasarkan kepada dalil-dalil yang jelas dan benar. (Mubarak, 2005: t.h.)

\section{Lembaga-lembaga Fatwa di Indonesia}

\section{Majelis Tarjih Muhammadiyah}

Majelis Tarjih baru berdiri 15 tahun setelah berdirinya Muhammadiyah, sebagai respon terhadap banyaknya perbedaan yang muncul seiring semakin banyaknya simpatisan dan anggotanya. Tepat pada Muktamar Muhammadiyah XVI di Pekalongan tahun 1927, diputuskan untuk membentuk Majelis Tarjih, yaitu suatu lembaga yang bertugas mengurusi dan membimbing masalahmasalah keagamaan yang timbul di lingkungan Muhammadiyah. Hal ini tertera dalam dokumen pendirian berikut: (Jamal dan Aziz, 2013: 187-188).

" ...bahwa perselisihan faham dalam masalah agama sudahlah timbul dari dahulu, dari sebelum lahirnja Muhammadijah: ........"

Oleh karena kita khawatir, adanya percekcokan dan perselisihan dalam kalangan Muhammadiyah tentang masalah agama itu, maka perlulah kita mendirikan Madjlis Tardjih ...........

(Suara Muhammadiyah: 1936: 145)

Di awal-awal berdirinya, lembaga ini belum mempunyai dasar-dasar teoritisnya. Beberapa usaha untuk menyusun dasar-dasar tersebut baru tercatat pada 1950 dan 1986. Di antara penyusunnya adalah Buya Hamka, K.H. Farid Ma'ruf, Mr. Kasman Singodimedjo, serta ZainJambek juga Ki Bagus Hadi Kusumo (Abdurrahman, 2004: 11-12).

Dengan demikian dapat disimpulkan Majelis Tarjih merupakan lembaga khusus yang membidangi masalah agama yang terdiri dari para ulama Muhammadiyah yang berkompeten di dalam melakukan ijtihad, guna menghadapi berbagai persoalan yang muncul di tengah- tengah masyarakat. Majelis Tarjih menerima ijtihad, termasuk qiyas, sebagai cara dalam menetapkan hukum yang tidak ada nashnya secara tegas. Majelis Tarjih tidak mengikatkan diri kepada suatu mazhab, tetapi pendapat-pendapat mazhab dapat menjadi bahan pertimbangan dalam menetapkan hukum sepanjang sesuai dengan Alquran dan Sunnah atau dasardasar lain yang kuat. (Febriansyah, 2013: 15-16) 


\section{Lajnah Bahtsul Masail NU}

LBM adalah singkatan dari Lajnah Bahtsul Masail. LBM merupakan salah satu lembaga Nahdatul Ulama (NU) yang bertugas membahas dan memecahkan persoalan di tengah masyarakat yang memerlukan kepastian hukum syariat Islam (Anonim, t.th.: 95).

LBM secara formal berdiri pada saat NU didirikan oleh KH. Hasyim Asya'ari tepat pada 31 Januari 1926. Namun, secara substansi, kegiatan Bahtsul Masail sudah dilaksanakan jauh sebelum NU berdiri. Kala itu, sudah berlaku tradisi diskusi di kalangan Pesantren yang melibatkan Kiai dan santri di mana hasilnya dimuat dalam bulletin Lailatul Ijtima Nahdlatul Oelama (LINO) (Jamal dan Aziz, 2013: 191).

Dalam perkembangannya, buletin ini tidak hanya menjadi media pemuat hasil diskusi tersebut, namun menjadi ajang diskusi interaktif di antara ulama Pesantren yang sebagian besar terpisah dengan jarak dan waktu yang jauh. Sekedar contoh adalah perdebatan antara KH. Mahfudz Salam Pati dengan KH. Murtadlo Tuban tentang boleh tidaknya teks khutbah Jum'at diterjemahkan ke dalam bahasa Jawa atau Indonesia. Kiai Salam berpendapat boleh menerjemahkan khutbah ke dalam bahasa bumi putera (baca: bahasa Indonesia) sedangkan Kiai Murtadlo berpendapat sebaliknya; tidak membolehkan penerjemahannya ke dalam bahasa apa pun kecuali mengatakannya dalam bahasa Arab (Lajnah Ta'lif Wan Nasyr NU Jawa Timur, 2007: VII).

Dilihat dari segi metode, forum Bahtsul Masail juga banyak mengadopsi metode pengkajian Islam yang banyak dikembangkan di Haramain (baca: Makkah dan Madinah); talaqqi. Yaitu seorang membacakan sebuah permasalahan lalu beberapa orang menanggapinya lalu disusul pendapat lain dan begitu juga seterusnya hingga ditemukan sebuah kesimpulan (Jamal dan Aziz, 2013: 192).

\section{Majelis Ulama Indonesia}

Majelis Ulama Indonesia adalah wadah atau majelis yang menghimpun para ulama, zu'ama dan cendekiawan muslim Indonesia untuk menyatukan gerak dan langkah-langkah umat Islam Indonesia dalam mewujudkan cita-cita bersama. Majelis Ulama Indonesia berdiri pada tanggal, 7 Rajab 1395 H, bertepatan dengan tanggal 26 Juli 1975 di Jakarta, sebagai hasil dari pertemuan atau musyawarah para ulama, cendekiawan dan zu'ama yang datang dari berbagai penjuru tanah air.

\section{Pengertian MUI}

Majelis Ulama Indonesia atau sering dikenal dengan istilah MUI terdiri dari tiga suku kata, Majelis yakni wadah atau perkumpulan, Ulama memiliki makna orang yang memiliki ilmu pengetahuan atau mengetahui akibat sesuatu (Ma'luf, t.th.: 527).

Majelis Ulama Indonesia adalah wadah musyawarah para ulama, zu'ama dan cendikiawan muslim yang kehadirannya bermanfaat untuk mengayomi dan menjaga umat. Selain itu MUI juga sebagai wadah silaturahim yang menggalang ukhuwah islamiyah, ukhuwah wathaniyah, dan ukhuwah insaniyah, demi mewujudkan kehidupan masyarakat yang harmonis, aman, damai, dan sejahtera dalam Negara Kesatuan Republik Indonesia.

Untuk melaksanakan fungsi dan tujuan di atas MUI melakukan upaya 
pendekatan yang proaktif, responsif dan preventif terhadap berbagai problemproblem itu sedini mungkin dapat diatasi, untuk tidak menimbulkan dampak yang lebih luas pada masyarakat khususnya umat Islam.

MUI merupakan sebuah lembaga yang mengayomi masyarakat dari berbagai isu-isu yang akan meresahkan dan memberikan fatwa untuk menjawab persoalan di tengah-tengah masyarakat yang majemuk seperti di Indonesia.

Dengan demikian dapat disimpulkan bahwa MUI adalah salah satu wadah di Indonesia yang berfungsi menegakkan syariat Islam di tengah masyarakat yang majemuk. Syariat Islam tidak hanya berupa akidah dan akhlak, tetapi meliputi seluruh hukum yang menyangkut hubungan dengan Allah, dan hukum yang berkaitan dengan muamalah, yakni hubungan sesama manusia dan alam sekitar. Karena itu syari'at Islam diturunkan menjadi rahmat kepada alam seluruhnya (Syahputra, t.th: 24). Hal ini tentunya sulit ditegakkan apabila tidak ada lembaga yang sah dan berwenang mengayomi masalah-masalah tesebut. Oleh sebab itu dibentuklah MUI sebagai jawaban atas kebutuhan masyarakat Islam di Indonesia.

\section{Sejarah MUI}

Majelis Ulama Indonesia berdiri pada tanggal, 7 Rajab $1395 \mathrm{H}$, bertepatan dengan tanggal 26 Juli 1975 di Jakarta, sebagai hasil dari pertemuan atau musyawarah para ulama, cendekiawan dan zu'ama yang datang dari berbagai penjuru tanah air.

Antara lain meliputi dua puluh enam orang ulama yang mewakili 26 Provinsi di Indonesia, 10 orang ulama yang merupakan unsur dari ormas-ormas Islam tingkat pusat, yaitu, NU, Muhammadiyah, Syarikat Islam, Perti. Al Washliyah, Math'laul Anwar, GUPPI, PTDI, DMI dan al Ittihadiyyah, 4 orang ulama dari Dinas Rohani Islam, AD, AU, AL dan POLRI serta 13 orang tokoh/cendekiawan yang merupakan tokoh perorangan.

Dari musyawarah tersebut, dihasilkan adalah sebuah kesepakatan untuk membentuk wadah tempat bermusyawarahnya para ulama, zu'ama dan cendekiawan muslim, yang tertuang dalam sebuah "PIAGAM BERDIRINYA MUI", yang ditandatangani oleh seluruh peserta musyawarah yang kemudian disebut Musyawarah Nasional Ulama.

Momentum berdirinya MUI bertepatan ketika bangsa Indonesia tengah berada pada fase kebangkitan kembali, setelah 30 tahun (1945-1975) merdeka, di mana energi bangsa telah banyak terserap dalam perjuangan politik kelompok dan kurang peduli terhadap masalah kesejahteraan rohani umat.

Ulama Indonesia menyadari sepenuhnya bahwa mereka adalah pewaris tugas-tugas para Nabi (Warasatul Anbiya). Maka mereka terpanggil untuk berperan aktif dalam membangun masyarakat melalui wadah MUI, seperti yang pernah dilakukan oleh para ulama pada zaman penajajahan dan perjuangan kemerdekaan. Di sisi lain umat Islam Indonesia menghadapi tantangan global yang sangat berat. Kemajuan sains dan teknologi yang dapat menggoyahkan batas etika dan moral, serta budaya global yang didominasi Barat, serta pendewaan kebendaan dan pendewaan hawa nafsu yang dapat melunturkan aspek religiusitas 
masyarakat serta meremehkan peran agama dalam kehidupan umat manusia.

Selain itu kemajuan dan keragaman umat Islam Indonesia dalam alam pikiran keagamaan, organisasi sosial, dan kecenderungan aliran dan aspirasi politik, sering mendatangkan kelemahan dan bahkan dapat menjadi sumber pertentangan di kalangan umat Islam sendiri.

Akibatnya umat Islam dapat terjebak dalam egoisme kelompok (ananiyah hizbiyah) yang berlebihan. Oleh karena itu kehadiran MUI, makin dirasakan kebutuhannya sebagai sebuah organisasi kepemimpinan umat Islam yang bersifat kolektif dalam rangka mewujudkan silaturrahmi, demi terciptanya persatuan dan kesatuan serta kebersamaan umat Islam.

Dalam perjalanannya, selama dua puluh lima tahun, Majelis Ulama Indonesia sebagai wadah musyawarah para ulama, zu'ama dan cendekiawan muslim berusaha untuk:

1. Memberikan bimbingan dan tuntunan kepada umat Islam Indonesia dalam mewujudkan kehidupan beragama dan bermasyarakat yang diridhoi Allah Swt.

2. Memberikan nasihat dan fatwa mengenai masalah keagamaan dan kemasyarakatan kepada Pemerintah dan masyarakat, meningkatkan kegiatan bagi terwujudnya ukhwah Islamiyah dan kerukunan antar-umat beragama dalam memantapkan persatuan dan kesatuan bangsa.

3. Menjadi penghubung antara ulama dan umaro (pemerintah).

4. Meningkatkan hubungan serta kerjasama antar organisasi, lembaga Islam dan cendekiawan muslimin dalam memberikan bimbingan dan tuntunan kepada masyarakat khususnya umat Islam dengan mengadakan konsultasi dan informasi secara timbal balik.

Dalam khitah pengabdian Majelis Ulama Indonesia telah dirumuskan lima fungsi dan peran utama MUI yaitu:

1. Sebagai pewaris tugas-tugas para Nabi (warasatul Anbiya).

2. Sebagai pemberi fatwa (mufti).

3. Sebagai pembimbing dan pelayan umat (riwayat wa khadim al ummah).

4. Sebagai gerakan Islah wa al Tajdid

5. Sebagai penegak amar ma'ruf dan nahi munkar

Sampai saat ini Majelis Ulama Indonesia mengalami beberapa kali kongres atau musyawarah nasional, dan mengalami beberapa kali pergantian Ketua Umum, dimulai dengan Prof. Dr. Hamka, KH. Syukri Ghozali, KH. Hasan Basri, Prof. KH. Ali Yafie dan kini KH. M. Sahal Maffudh. Ketua Umum MUI yang pertama, kedua dan ketiga telah meninggal dunia dan mengakhiri tugastugasnya. Sedangkan dua yang terakhir masih terus berkhidmah untuk memimpin majelis para ulama ini.

Demikianlah sekilas tentang Majelis Ulama Indonesia (MUI, http://mui.or.id, diakses pada 15 Juni 2017). MUI memiliki peranan yang sangat besar terhadap kehidupan masyarakat. Tanpa adanya MUI sebagai lembaga independen yang berwenang mengatasi problem masyarakat, maka akan sulit menegakkan Islam dan hukum Islam di Indonesia disebabkan pengaruh globalisasi dan modernisasi yang membawa Indonesia lebih kepada kiblat barat yang orientalis dan merusak bangsa. 


\section{Konsep Zakat}

\section{Definisi Zakat}

Secara etimologis, zakat berasal dari kata dasar bahasa Arab zaka yang berarti berkah, tumbuh, bersih, baik, dan bertambah. Sedangkan secara terminologis di dalam fikih, zakat adalah sebutan atau nama bagi sejumlah harta tertentu yang diwajibkan Allah Swt supaya diserahkan kepada orang-orang yang berhak (mustahiq) oleh orang-orang yang wajib mengeluarkan zakat (muzaki) (Ambary, dkk., 1999: 224).

Berdasarkan pengertian secara istilah tersebut, meskipun para ulama mengemukakan dengan redaksi yang agak berbeda antara satu dengan yang lainnya, akan tetapi pada prinsipnya sama. Jadi zakat adalah bagian dari harta dengan persyaratan tertentu, yang Allah Swt mewajibkan kepada pemiliknya, untuk diserahkan kepada pihak yang berhak menerimanya, dengan persyaratan tertentu pula. Sedangkan menurut ketentuan umum pasal 1 ayat 2 UndangUndang Republik Indonesia Nomor 23 Tahun 2011 tentang Pengelolaan Zakat, yang dimaksud dengan zakat adalah harta yang wajib di keluarkan oleh seorang muslim atau badan usaha untuk diberikan kepada yang berhak menerimanya sesuai dengan syariat Islam.

Zakat dan keberkahan mempunyai hubungan yang erat sekali, yaitu bahwa setiap harta yang dikeluarkan zakatnya akan menjadi berkah, tumbuh, berkembang dan bertambah, suci dan baik (Hafidhuddin, 2002: 7).

Ada pendapat beberapa ulama mengenai pengertian zakat, yaitu (Al Zuhayly, 1995: 83-84):

1. Menurut mazhab Maliki, definisi zakat adalah "mengeluarkan sebagian yang khusus dari harta yang khusus pula yang telah mencapai nisab (batas kuantitas yang mewajibkan zakat) kepada orangorang yang berhak menerimanya (mustahiq)nya. Dengan catatan, kepemilikan itu penuh dan mencapai haul (setahun), bukan barang tambang dan bukan pertanian."

2. Menurut mazhab Hanafi, zakat adalah "menjadikan sebagian harta yang khusus dari harta yang khusus sebagai milik orang yang khusus, yang ditentukan oleh syari'at karena Allah Swt."

3. Menurut mazhab Syafi'i, zakat adalah sebuah ungkapan untuk keluarnya harta atau tubuh sesuai dengan cara khusus.

4. Menurut mazhab Hambali, zakat adalah hak yang wajib (dikeluarkan) dari harta yang khusus untuk kelompok yang khusus pula.

Menurut istilah ekonomi, zakat merupakan tindakan pemindahan kekayaan dari golongan kaya kepada golongan tidak punya. Salah satu ajaran penting yang terdapat dalam agama Islam adalah urgensi zakat kaitannya dengan pengentasan kemiskinan. Sebagai sebuah dinamika keagamaan, zakat merupakan bentuk kesaksian manusia (syahadah alinsan) pada rukun Islam yang keempat di hadapan Allah yang muaranya tertuju pada dimensi kemanusiaan.

\section{Landasan Kewajiban Zakat}

Zakat telah diwajibkan di Madinah pada bulan Syawal tahun kedua hijrah setelah kepada umat Islam diwajibkan berpuasa Ramadhan.

Zakat merupakan salah satu rukun Islam yang selalu disejajarkan dengan shalat. Inilah yang menunjukkan betapa pentingnya zakat sebagai salah satu rukun 
Islam. Dasar-dasar atau landasan kewajiban mengeluarkan zakat disebutkan dalam:

\section{Landasan dalam Alquran}

1. Surat al-Baqarah: 43

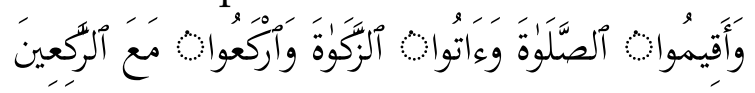

Dan dirikanlah shalat, tunaikanlah zakat dan ruku'lah beserta orang-orang yang ruku' (Q.S. al-Baqarah [2]: 43).

2. Surat at-Taubah: 103

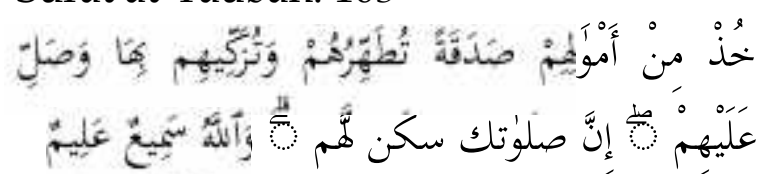

Ambillah zakat dari sebagian harta mereka, dengan zakat itu kamu membersihkan dan mensucikan mereka dan mendoalah untuk mereka. Sesungguhnya doa kamu itu (menjadi) ketenteraman jiwa bagi mereka. dan Allah Maha mendengar lagi Maha Mengetahui (Q.S. at-Taubah [9]: 103).

3. Surat al-An'am: 141

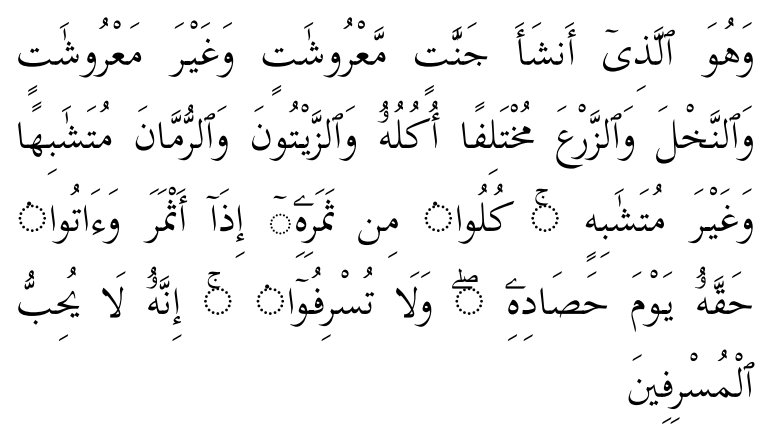

Dan Dialah yang menjadikan kebunkebun yang berjunjung dan yang tidak berjunjung, pohon korma, tanamtanaman yang bermacam-macam buahnya, zaitun dan delima yang serupa (bentuk dan warnanya) dan tidak sama (rasanya). Makanlah dari buahnya (yang bermacam-macam itu) bila dia berbuah, dan tunaikanlah haknya di hari memetik hasilnya (dengan disedekahkan kepada fakir miskin); dan janganlah kamu berlebih-lebihan. Sesungguhnya Allah tidak menyukai orang yang berlebih-lebihan (Q.S. al-An'am [6]: 141).

4. Surat at-Taubah: 5

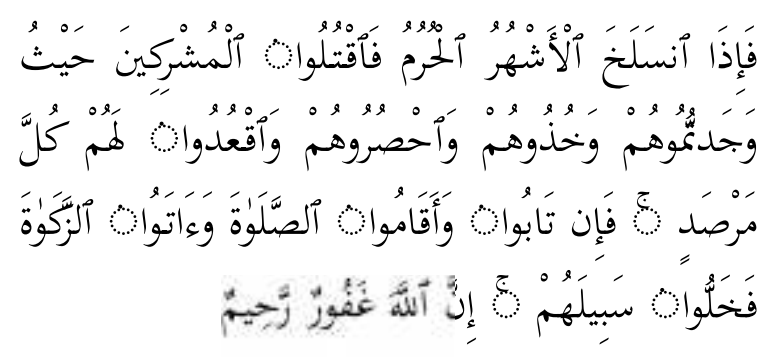

Apabila sudah habis bulan-bulan haram itu maka bunuhlah orang-orang musyrikin itu di mana saja kamu jumpai mereka, dan tangkaplah mereka. Kepunglah mereka dan intailah di tempat pengintaian. Jika mereka bertaubat dan mendirikan shalat dan menunaikan zakat, maka berilah kebebasan kepada mereka untuk berjalan. Sesungguhnya Allah Maha Pengampun lagi Maha Penyayang (Q.S. at-Taubah [9]: 5)

\section{Landasan dalam Sunnah}

1. Hadis yang diriwayatkan oleh Bukhari dan Muslim dari Abdullah bin Umar Rasulullah bersabda:

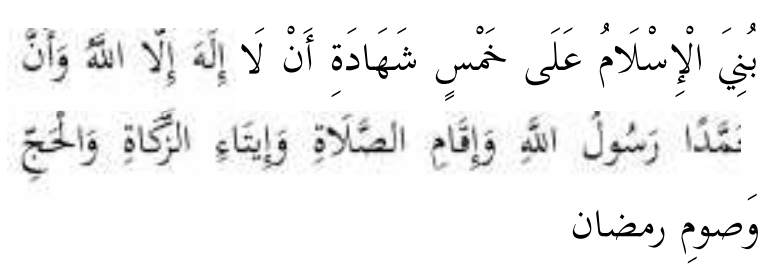

Islam dibangun di atas lima (landasan); persaksian tidak ada Ilah selain Allah dan sesungguhnya Muhammad utusan Allah, mendirikan shalat, menunaikan zakat, haji dan puasa Ramadhan (H.R. Bukhari Nomor 7)

2. Hadis yang diriwayatkan oleh Ahmad dan Muslim dari Syaiban bin Farrukh 


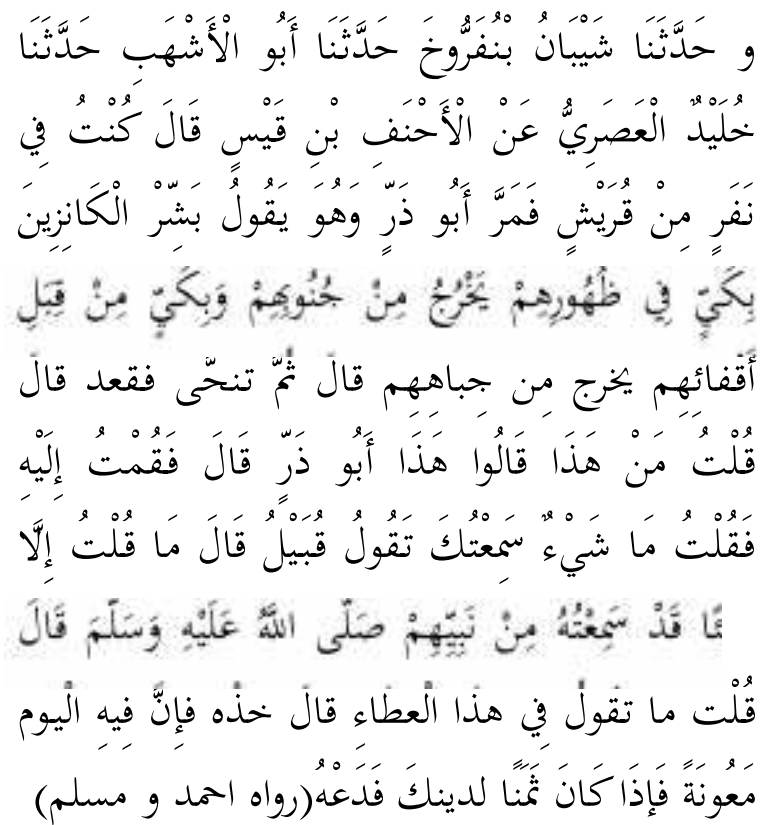

Dan Telah menceritakan kepada kami [Syaiban bin Farrukh] telah menceritakan kepada kami [Abul Asyhab] telah menceritakan kepada kami [Khulaid Al 'Ashari] dari [Al Ahnaf bin Qais] ia berkata; Saya pernah berada dalam sebuah rombongan orang-orang Quraisy, lalu [Abu Dzar] lewat sambil mengatakan, "Berilah kabar gembira kepada orang-orang yang menumpuk harta (dan tidak membayar zakatnya), bahwa mereka akan disiksa dengan seterika di punggung mereka yang keluar dari lambung dari tengkuk mereka." Setelah itu, ia menyingkir dan duduk. Kemudian saya bertanya, "Siapa ini?" orang-orang pun menjawab, "Ini adalah Abu Dzar." Maka aku pun mendekatinya dan bertanya, "Apa ucapanmu yang baru saja aku dengar tadi?" Abu Dzar menjawab, "Tidaklah aku mengatakan sesuatu tadi, kecuali aku telah mendengarnya dari Nabi shallallahu 'alaihi wasallam." Kemudian aku tanyakan, "Bagaimana pendapatmu tentang pemberian ini?" Abu Dzar menjawab, "Ambillah karena pemberian itu sekarang sebagai pertolongan, namun jika pemberian itu untuk membayar agamamu, maka tinggalkanlah. (H.R. Ahmad Nomor 20511 dan Muslim Nomor 1657)

3. Hadis yang diriwayatkan oleh Thabrani dalam buku Al Ausath dan As Saghir dari Ali

$$
\begin{aligned}
& \text { ان الله فرض على اغنياء المسا عين في اموا لهم بقد ر }
\end{aligned}
$$

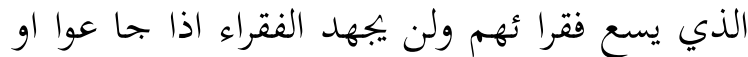

$$
\begin{aligned}
& \text { عروا الا بما يصنع اغنيا ئهم الا وان الله يحا سبهم } \\
& \text { حسابا شديدا و يعذ بكم عذابااليما }
\end{aligned}
$$

Allah Ta'ala mewajibkan zakat pada harta orang-orang kaya dari kaum muslimin sejumlah yang dapat melapangi orang-orang miskin di antara mereka. Fakir miskin itu tiadalah akan menderita menghadapi kelaparan dan kesulitan sandang kecuali karena perbuatan golongan kaya, ingatlah Allah akan mengadili mereka nanti secara tegas dan menyiksa mereka dengan pedih (H.R. Thabrani)

\section{Prinsip-prinsip Zakat}

Sebagai suatu kewajiban yang harus ditunaikan, tidak setiap harta harus dikeluarkan zakatnya. Namun ada prinsip-prinsip yang mengatur. Diantaranya adalah sebagai berikut:

1. Prinsip keyakinan agama (faith) Bahwa orang yang membayar zakat yakin bahwa pembayaran tersebut merupakan salah satu manifestasi keyakinan agamanya, sehingga orang yang belum menuneikan zakat merasa tidak sempurna dalam menjalankan ibadahnya. 
2. Prinsip pemerataan (equity) dan keadilan

Prinsip pemerataan dan keadilan cukup jelas menggambarkan tujuan zakat, yaitu membagi lebih adil kekayaan yang telah diberikan Tuhan kepada umat manusia.

3. Prinsip produktifitas (productivity) dan kematangan

Prinsip produktivitas dan kematangan menekankan bahwa zakat memang wajar harus dibayar karena milik tertentu telah menghasilkan produk tertentu. Hasil produksi tersebut hanya dapat dipungut setelah melampaui jangka waktu satu tahun yang merupakan ukuran normal memperoleh hasil tertentu.

4. Prinsip nalar (reason)

Bahwa menurut nalar manusia harta yang disimpan dan dibelanjakan untuk Allah, tidak akan berkurang melainkan akan bertambah banyak.

5. Prinsip kebebasan (freedom)

Prinsip kebebasan menjelaskan bahwa zakat hanya dibayarkan oleh orang yang bebas dan sehat jasmani serta rohaninya, yang mempunyai tanggung jawab untuk membayar zakat untuk kepentingan bersama.

6. Prinsip etik (ethic) dan kewajaran

Prinsip etik dan kewajaran menyatakan bahwa zakat tidak dipungut secara semena-mena tanpa memperhatikan akibat yang akan ditimbulkan (Anshori, 2006: 20-21).

\section{Macam-macam Zakat}

Zakat terdiri atas 2 macam, yaitu:

1. Zakat nafs (jiwa)

Disebut juga dengan zakat fitrah, merupakan zakat untuk menyucikan diri. Dikeluarkan dan disalurkan kepada yang berhak pada bulan ramadhan sebelum tanggal 1 Syawal (hari raya Idul Fitri). Zakat fitrah diwajibkan pada tahun kedua hijriyah. Ukuran zakat perjiwa yang dikeluarkan adalah satu sha' $\left(3^{1} / 2\right.$ liter) makanan pokok (Depag, 1983: 267) atau bisa berupa uang yang nilainya sebanding dengan ukuran/harga bahan pangan atau makanan pokok tersebut.

2. Zakat Mal atau zakat harta

Yaitu zakat yang dikeluarkan untuk menyucikan harta, apabila harta itu telah memenuhi syarat-syarat wajib zakat. Yusuf Qardhawi (2002:121) dalam bukunya "Hukum Zakat" menjelaskan mengenai kekayaan yang wajib dizakati, yaitu:

a. Zakat binatang ternak

b. Zakat emas dan perak

c. Zakat dagang

d. Zakat pertanian (tanaman dan buahbuahan)

e. Madu dan produksi hewan

f. Barang tambang dan hasil laut

g. Investasi pabrik, gedung

h. Zakat pendapatan usaha (profesi)

Uraian di atas dapat disimpulkan bahwa pada dasarnya setiap harta kekayaan yang produktif dan bernilai ekonomis apabila mencapai nishab maka wajib dikeluarkan zakatnya. Seperti pada surat Al-Baqarah ayat 267 yaitu sebagai berikut:

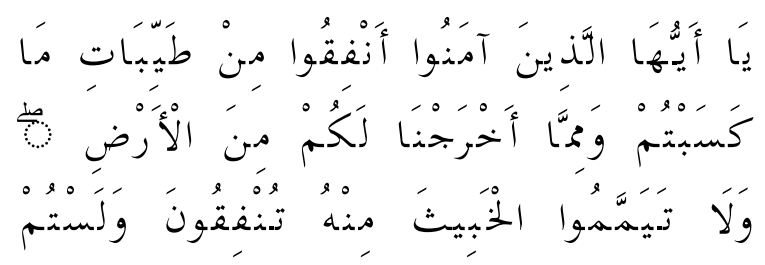




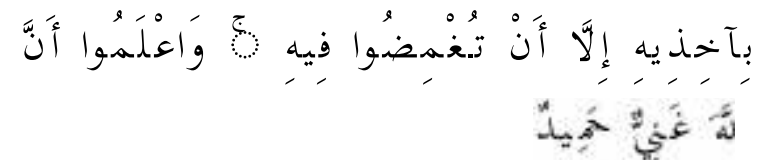

Hai orang-orang yang beriman, nafkahkanlah (di jalan Allah) sebagian dari hasil usahamu yang baik-baik dan sebagian dari apa yang Kami keluarkan dari bumi untuk kamu. Dan janganlah kamu memilih yang buruk-buruk lalu kamu menafkahkan daripadanya, padahal kamu sendiri tidak mau mengambilnya melainkan dengan memincingkan mata terhadapnya. Dan ketahuilah, bahwa Allah Maha Kaya lagi Maha Terpuji. (Q.S. Al-Baqarah [2]: 267)

Dari penjelasan tersebut, dapat dipahami bahwa kewajiban mengeluarkan zakat itu dikenakan pada setiap harta kekayaan yang halal dan diperoleh dengan cara yang halal pula, baik hasil usaha atau jasa, maupun berupa buahbuhan, binatang ternak, dan kekayaan lain- lainnya.

\section{Syarat Zakat}

Ada beberapa syarat yang harus dipenuhi terhadap harta kekayaan yang dipunyai oleh saeorang muslim. Syaratsyarat tersebut adalah:

1. Pemilikan yang pasti, halal dan baik. Artinya, sepenuhnya berada dalam kekuasaan yang punya, baik kekuasaan pemanfaatan maupun kekuasaan menikmati hasilnya.

2. Berkembang, artinya, harta itu berkembang, baik secara alami berdasarkan sunnatullah maupun bertanbah karena ikhtiar atau usaha manusia.

3. Melebihi kebutuhan pokok. Harta yang dimiliki oleh seseorang itu melebihi kebutuhan pokok yang diperlukan bagi diri sendiri dan keluarganya untuk hidup wajar sebagai manusia.
4. Bersih dari hutang

5. Mencapai nishab, harta yang dimiliki oleh muzaki telah mencapai jumlah (kadar) minimal yang harus dikeluarkan zakatnya.

6. Mencapai haul, harta mencapai waktu tertentu pengeluaran zakat, biasanya dua belas bulan qomariyah, atau setiap kali setelah menuai. Harta yang tidak ditentukan haul setiap tahun adalah tumbuh-tumbuhan ketika menuai dan barang temua ketika ditemukan (Anshori, 2006: 28-29).

\section{Hikmah Zakat}

Zakat adalah ibadah dalam bidang harta yang mengandung manfaat dan hikmah yang demikian besar dan mulia, baik yang berkaitan dengan muzaki, mustahiq, harta yang dikeluarka zakatnya, maupun bagi masyarakat keseluruhan. Adapun hikmah tersebut antara lain sebagai berikut:

1. Zakat merupakan pertolongan bagi orang-orang fakir dan orang-orang yang sangat membutuhkan bantuan. Zakat bisa mendorong mereka untuk bekerja dengan semangat dan bisa meraih kehidupan yang layak. Dengan demikian masyarakat akan terhindar dari kemiskinan (Al- Zuhayly, 1995: 87).

2. Membersihkan dan menyuburkan harta.

3. Mewujudkan rasa syukur terhadap nikmat yang dikaruniakan oleh Allah Swt (Anshori, 2006: 55).

4. Mensucikan jiwa dari penyakit kikir dan bakhil, dengan zakat dapat melatih seorang mukmin untuk bersifat dermawan (Al-Zuhayly, 1995: 88).

5. Mewujudkan kesatuan di kalangan masyarakat Islam dalam urusan 
ekonomi dan keuangan. Sehingga zakat akan menciptakan kesejahteraan dari sudut ekonomi dan kebudayaan (Anshori, 2006: 56)

\section{Fatwa MUI tentang Masalah Zakat}

MUI sudah berusaha menjawab persoalan umat yang begitu kompleks, masalah zakat merupakan salah satu bagian pembahasannya mulai dari tahun 1982 s.d. 2011, dalam rentang tersebut sudah terhimpun 10 fatwa MUI yang membahas zakat (Sam, et.al, 2011: 1-91). Fatwa MUI tentang masalah zakat, sebagai berikut:

\section{Tahun 1982}

Beberapa fatwa tentang persoalan zakat pada tahun 1982, yaitu:

1. Intensifikasi Pelaksanaan Zakat

Komisi Fatwa Majelis Ulama Indonesia dalam sidangnya pada tanggal 1 Rabi'ul Akhir $1402 \mathrm{H}$, bertepatan dengan tanggal 26 Januari 1982 M, menetapkan:

a. Penghasilan dari jasa dapat dikenakan zakat apabila sampai nisab dan haul.

b. Yang berhak menerima zakat hanya delapan ashnaf yang tersebut dalam Alquran pada surat at-Taubah ayat 60. Apabila salah satu ashnaf tidak ada, bagiannya diberikan kepada ashnaf yang ada.

c. Untuk kepentingan dan kemaslahatan umat Islam, maka yang tidak dapat dipungut melalui saluran zakat, dapat diminta atas nama infaq atau shadaqah.

d. Infaq dan shadaqah yang diatur pungutannya oleh Ulil Amri, untuk kepentingan tersebut di atas, wajib ditaati oleh umat Islam menurut kemampuannya.
2. Men-tasharuf-kan Dana Zakat untuk Kegiatan Produktif dan Kemaslahatan Umum

Komisi Fatwa Majelis Ulama Indonesia dalam sidangnya pada tanggal 8 Rabi'ul Akhir $1402 \mathrm{H}$, bertepatan dengan tanggal 2 Februari $1982 \mathrm{M}$, setelah melalui mekanisme menetapkan:

a. Zakat yang diberikan kepada fakir miskin dapat bersifat produktif.

b. Dana zakat atas nama Sabilillah boleh di-tasharuf-kan guna keperluan maslahah 'ammah (kepentingan umum).

\section{Tahun 1996}

Beberapa fatwa tentang persoalan zakat pada tahun 1996, yaitu Pemberian Zakat untuk Beasiswa. Sebagaimana tertuang dalam Lampiran Surat Fatwa Majelis Ulama Indonesia tentang Pemberian Zakat Untuk Beasiswa Nomor Kep. 120/MU/II/1996.

Dewan Pimpinan Majelis Ulama Indonesia menyampaikan bahwa pada hari Sabtu tanggal 20 Ramadhan 1416 Hijriah, bertepatan dengan tanggal 10 Februari 1996 Miladiyah, dilanjutkan pada hari Rabu 24 Ramadhan 1416 Hijriah, bertepatan tanggal 14 Februari 1996 Miladiyah, Komisi Fatwa Majelis Ulama Indonesia telah bersidang untuk membahas pemberian zakat untuk beasiswa, yaitu :

Bagaimana hukum pemberian zakat untuk keperluan pendidikan, khususnya pemberian beasiswa?

Sehubungan dengan masalah tersebut sidang merumuskan sebagai berikut:

Memberikan uang zakat untuk keperluan pendidikan, khususnya dalam 
bentuk beasiswa, hukumnya adalah sah, karena termasuk dalam ashnaf fi sabilillah, yaitu bantuan yang dikeluarkan dari dana zakat berdasarkan Alquran surat AtTaubah ayat 60 dengan alasan bahwa pengertian fi sabilillah menurut sebagian ulama figh dari beberapa mazhab dan ulama tafsir adalah "lafaznya umum". Oleh karena itu, berlakulah kaidah ushuliyah:

Sidang memberikan pertimbangan bahwa pelajar/ mahasiswa/ sarjana muslim, penerima zakat beasiswa, hendaknya:

1. Berprestasi akademik.

2. Diprioritaskan bagi mereka yang kurang mampu.

3. Mempelajari ilmu pengetahuan yang bermanfaat bagi bangsa Indonesia.

\section{Tahun 2003}

Fatwa tentang persoalan zakat pada tahun 2003, yaitu:

1. Zakat Penghasilan.

Hal ini tertuang dalam Fatwa Majelis Ulama Indonesia Nomor 3 Tahun 2003 tentang Zakat Penghasilan.

a. Ketentuan Umum

Dalam Fatwa ini, yang dimaksud dengan "penghasilan" adalah setiap pendapatan seperti gaji, honorarium, upah, jasa, dan lain- lain yang diperoleh dengan cara halal, baik rutin seperti pejabat negara, pegawai atau karyawan, maupub tidak rutin seperti dokter, pengacara, konsultan, dan sejenisnya, serta pendapatan yang diperoleh dari pekerjaan bebas lainnya. b. Hukum

Semua bentuk penghasilan halal wajib dikeluarkan zakatnya dengan syarat telah mencapai nishab dalam satu tahun, yakni senilai emas 85 gram.

c. Waktu Pengeluaran Zakat

1) Zakat penghasilan dapat dikeluarkan pada saat menerima jika sudah cukup nishab.

2) Jika tidak mencapai nishab, maka semua penghasilan dikumpulkan selama satu tahun; kemudian zakat dikeluarkan jika penghasilan bersihnya sudah cukup nishab.

d. Kadar Zakat

Kadar zakat penghasilan adalah $2,5 \%$.

2. Penggunaan Dana Zakat untuk Istitsmar

Hal ini tertuang dalam Fatwa Majelis Ulama Indonesia Nomor 4 Tahun 2003 tentang Penggunaan Dana Zakat Untuk Istitsmar (Investasi). MUI menetapkan:

a. Zakat mal harus dikeluarkan sesegera mungkin (fauriyah), baik dari muzaki kepada amil maupun dari amil kepada mustahik.

b. Penyaluran (tauzi'/distribusi) zakat mal dari amil kepada mustahiq, walaupun pada dasarnya harus fauriyah, dapat di-ta'khir-kan apabila mustahiqnya belum ada atau ada kemaslahatan yang lebih besar.

c. Maslahat ditentukan oleh Pemerintah dengan berpegang pada aturan-aturan kemaslahatan sehingga maslahat tersebut merupakan maslahat syar'iyah. 
d. Zakat yang di-ta 'khir-kan boleh diinvestasikan (istitsmar) dengan syarat-syarat sebagai berikut:

1) Hams disalurkan pada usaha yang dibenarkan oleh syariah dan peraturan yang berlaku (althuruq al-masyru 'ah)

2) Diinvestasikan pada bidangbidang usaha yang diyakini akan memberikan keuntungan atas dasar studi kelayakan.

3) Dibina dan diawasi oleh pihakpihak yang memiliki kompetensi.

4) Dilakukan oleh institusil lembaga yang profesional dan dapat dipercaya (amanah).

5) 1zin investasi (istitsmar) hams diperoleh dari Pemerintah dan Pemerintah harus menggantinya apabila terjadi kerugian atau pailit.

6) Tidak ada fakir miskin yang kelaparan atau memerlukan biaya yang tidak bisa ditunda pada saat harta zakat itu diinvestasikan.

7) Pembagian zakat yang di-ta'khirkan karena diinvestasikan harus dibatasi waktunya.

\section{Tahun 2009}

Pada tahun ini pembahasan masalah zakat menghasilkan fatwa MUI yang berupa Keputusan Komisi B1 Ijtima' Ulama Komisi Fatwa MUI se-Indonesia III tentang Masail Fighiyyah Mu'ashirah (Masalah Fikih Kontemporer) pada 26 Januari 2009/ 29 Muharram 1430 H, yang memuat:

Ketentuan Hukum

1. Defenisi, Tugas, dan Fungsi, Kewajiban, dan Hak-hak Amil a. Definisi, Tugas, Fungsi, Kewajiban dan Hak-hak Amil

Definisi 'amil adalah seseorang atau sekelompok orang yang ditunjuk/ disahkan oleh pemerintah untuk mengurus zakat, tugas 'amil adalah memungut (dari orang kaya) dan menyalurkan kepada mustahiq, fungsi 'amil adalah sebagai pelaksana segala kegiatan urusan zakat yang meliputi pengumpulan, pencatatan (administrasi), dan pendistribusian, kewajiban 'amil adalah melakukan pencacatan data muzakki, para mustahiq, memungut atau menerima, mengetahui jumlah dan besarnya kebutuhan mustahiq dan menyerahkan harta zakat dengan baik dan benar, hak 'amil adalah menerima bagian dari harta zakat untuk melaksanakan seluruh tugas-tugasnya maksimal seperdelapan $(12,5 \%)$ dari harta zakat, dan jika ada kekurangan boleh diambilkan dana di luar zakat.

b. Amil tidak boleh meminta ongkos di luar hak-hak (bagian) amil karena amil tidak boleh menerima pemberian hadiah dari muzakki apalagi meminta ongkos di luar hak amil meskipun untuk operasional amil.

2. a. Amil tidak boleh memberikan hadiah kepada muzakki yang berasal dari harta zakat.

b. Amil tidak boleh menerima hadiah dari muzakki dalam kaitan tugasnya sebagai amil.

3. Biaya yang ditimbulkan karena tugas penyaluran zakat baik langsung atau tidak langsung bersumber dari porsi bagian amil. Apabila tidak mencukupi dapat diambil dari dana di luar zakat. 
4. Perusahaan yang telah memenuhi syarat wajib zakat, wajib mengeluarkan zakat, baik sebagai syakhshiyyah i'tibariyyah ataupun sebagai pengganti (wakil) dari pemegang saham.

Rekomendasi:

1. Pemerintah Pusat dan Pemerintah Daerah diminta mengalokasikan anggaran bagi Badan Amil Zakat (BAZ) dan Lembaga Amil Zakat (LAZ) agar dapat melaksanakan tugasnya, secara efektif dan produktif.

2. Pengelola BAZ dan LAZ diminta agar melakukan konsultasi kepada Ulama dalam setiap pengambilan kebijakan terkait dengan masalah fikih zakatnya.

3. MUI Pusat diharapkan memberikan penjelasan lebih rinci terhadap keputusan yang masih perlu penjelasan, misalnya tentang zakat perusahaan.

\section{Tahun 2011}

1. Fatwa MUI tentang Amil

Fatwa MUI Nomor 8 Tahun 2011 tentang Amil Zakat, yaitu:

a. Amil zakat adalah:

1) Seseorang atau sekelompok orang yang diangkat oleh Pemerintah untuk mengelola pelaksanaan ibadah zakat; atau

2) Seseorang atau sekelompok orang yang dibentuk oleh masyarakat dan disahkan oleh Pemerintah untuk mengelola pelaksanaan ibadah zakat.

b. Amil zakat harus memenuhi syarat sebagai berikut:

1) Beragama Islam;

2) Mukallaf (berakal dan baligh);

3) Amanah;

4) Memiliki ilmu pengetahuan tentang hukum-hukum zakat dan hal lain yang terkait dengan tugas amil zakat.

c. Amil zakat memiliki tugas:
1) Penarikan/pengumpulan zakat yang meliputi pendataan wajib zakat, penentuan objek wajib zakat, besaran nisab zakat, besaran tarif zakat, dan syarat-syarat tertentu pada masing-masing objek wajib zakat;

2) Pemeliharaan zakat yang meliputi inventarisasi harta, pemeliharaan, serta pengamanan harta zakat; dan

3) Pendistribusian zakat yang meliputi penyaluran harta zakat agar sampai kepada mustahik zakat secara baik dan benar, dan termasuk pelaporan.

d. Pada dasarnya, biaya operasional pengelolaan zakat disediakan oleh Pemerintah (ulil amr).

e. Dalam hal biaya operasional tidak dibiayai oleh Pemerintah, atau disediakan Pemerintah tetapi tidak mencukupi, maka biaya operasional pengelolaan zakat yang menjadi tugas amil diambil dari dana zakat yang merupakan bagian amil atau dari bagian Fi Sabilillah dalam batas kewajaran, atau diambil dari dana di luar zakat.

f. Kegiatan untuk membangun kesadaran berzakat seperti iklan dapat dibiayai dari dana zakat yang menjadi bagian amil atau Fi Sabilillah dalam batas kewajaran, proporsional dan sesuai dengan kaidah syariat Islam.

g. Amil zakat yang telah memperoleh gaji dari negara atau lembaga swasta dalam tugasnya sebagai amil tidak berhak menerima bagian dari dana zakat yang menjadi bagian amil. Sementara amil zakat yang tidak memperoleh gaji dari negara atau lembaga swasta berhak menerima 
bagian dari dana zakat yang menjadi bagian amil sebagai imbalan atas dasar prinsip kewajaran.

h. Amil tidak boleh menerima hadiah dari muzaki dalam kaitan tugasnya sebagai amil.

i. Amil tidak boleh memberi hadiah kepada muzaki yang berasal dari harta zakat.

2. Hukum Zakat atas harta Haram

Fatwa Majelis Ulama Indonesia Nomor: 13 Tahun 2011 tentang Hukum Zakat atas Harta Haram, yaitu:

a. Ketentuan Hukum

1. Zakat wajib ditunaikan dari harta yang halal, baik hartanya maupun cara perolehannya.

2. Harta haram tidak menjadi obyek wajib zakat.

3. Kewajiban bagi pemilik harta haram adalah bertaubat dan membebaskan tanggung jawab dirinya dari harta haram tersebut.

4. Cara bertaubat sebagaimana dimaksud angka 3 adalah sebagai berikut:

a) Meminta ampun kepada Allah, menyesali perbuatannya, dan ada keinginan kuat ('azam) untuk tidak mengulangi perbuatannya;

b) Bagi harta yang haram karena didapat dengan cara mengambil sesuatu yang bukan haknya seperti mencuri dan korupsi, maka harta tersebut harus dikembalikan seutuhnya kepada pemiliknya. Namun, jika pemiliknya tidak ditemukan, maka digunakan untuk kemaslahatan umum. c) Bila harta tersebut adalah hasil usaha yang tidak halal seperti perdangan minuman keras dan bunga bank maka hasil usaha tersebut (bukan pokok modal) secara keseluruhan harus digunakan untuk kemaslahatan umum.

\section{b. Ketentuan Penutup}

1) Fatwa ini mulai berlaku pada tanggal ditetapkan, dengan ketentuan jika di kemudian hari ternyata terdapat kekeliruan, akan diperbaiki dan disempurnakan sebagaimana mestinya.

2) Agar setiap muslim dan pihakpihak yang memerlukan dapat mengetahuinya, semua pihak dihimbau untuk menyebarluaskan fatwa ini.

3. Penarikan, Pemeliharaan, dan Penyaluran Harta Zakat

Fatwa Majelis Ulama Indonesia Nomor: 14 Tahun 2011 tentang Penarikan, Pemeliharaan, dan Penyaluran Harta Zakat, yaitu:

a. Ketentuan Umum

Dalam fatwa ini yang dimaksud dengan:

1) Penarikan zakat adalah kegiatan pengumpulan harta zakat yang meliputi pendataan wajib zakat, penentuan objek wajib zakat, besaran nishab zakat, besaran tarif zakat, dan syarat-syarat tertentu pada masing-masing objek wajib zakat.

2) Pemeliharaan zakat adalah kegiatan pengelolaan yang meliputi inventarisasi harta, pemeliharaan, serta pengamanan harta zakat. 
3) Penyaluran zakat adalah kegiatan pendistribusian harta zakat agar sampai kepada para mustahiq zakat secara benar dan baik.

4) Zakat muqayyadah adalah zakat yang telah ditentukan mustahiqnya oleh muzakki, baik tentang ashnaf, orang perorang, maupun lokasinya.

b. Ketentuan Hukum

1) Penarikan zakat menjadi kewajiban amil zakat yang dilakukan secara aktif.

2) Pemeliharan zakat merupakan tanggung jawab amil sampai didistribusikannya dengan prinsip yadul amanah.

3) Apabila amil sudah melaksanakan tugasnya dengan baik, namun di luar kemampuannya terjadi kerusakan atau kehilangan maka amil tidak dibebani tanggung jawab penggantian.

4) Penyaluran harta zakat dari amil zakat kepada amil zakat lainnya belum dianggap sebagai penyaluran zakat hingga harta zakat tersebut sampai kepada para mustahiq zakat.

5) Dalam hal penyaluran zakat sebagaimana nomor 4, maka pengambilan hak dana zakat yang menjadi bagian amil hanya dilakukan sekali. Sedangkan amil zakat yang lain hanya dapat meminta biaya operasional penyaluran harta zakat tersebut kepada amil yang mengambil dana.

6) Yayasan atau lembaga yang melayani fakir miskin boleh menerima zakat atas nama $f i$ sabilillah. Biaya operasional penyaluran harta zakat tersebut mengacu kepada ketentuan angka 5.

7) Penyaluran zakat muqayyadah, apabila membutuhkan biaya tambahan dalam distribusinya, maka Amil dapat memintanya kepada mustahiq. Namun apabila penyaluran zakat muqayyadah tersebut tidak membutuhkan biaya tambahan, misalnya zakat muqayyadah itu berada dalam pola distribusi amil, maka amil tidak boleh meminta biaya tambahan kepada muzakki.

\section{c. Ketentuan Penutup}

1) Fatwa ini mulai berlaku pada tanggal ditetapkan, dengan ketentuan jika di kemudian hari ternyata terdapat kekeliruan, akan diperbaiki dan disempurnakan sebagaimana mestinya.

2) Agar setiap muslim dan pihakpihak yang memerlukan dapat mengetahuinya, semua pihak dihimbau untuk menyebarluaskan fatwa ini.

4. Penyaluran Harta Zakat dalam Bentuk Aset Kelolaan

Fatwa Majelis Ulama Indonesia Nomor: 15 Tahun 2011 tentang Penyaluran Harta Zakat dalam Bentuk Aset Kelolaan, yaitu:

a. Ketentuan Umum

Dalam fatwa ini yang dimaksud dengan:

Aset kelolaan adalah sarana dan/atau prasarana yang diadakan dari harta zakat dan secara fisik berada di dalam pengelolaan pengelola sebagai wakil mustahiq zakat, 
sementara manfaatnya diperuntukkan bagi mustahiq zakat.

b. Ketentuan Hukum

Hukum penyaluran harta zakat dalam bentuk aset kelolaan adalah boleh dengan ketentuan sebagai berikut:

1) Tidak ada kebutuhan mendesak bagi para mustahiq untuk menerima harta zakat.

2) Manfaat dari aset kelolaan hanya diperuntukkan bagi para mustahiq zakat.

3) Bagi selain mustahiq zakat dibolehkan memanfaatkan aset kelolaan yang diperuntukkan bagi para mustahiq zakat dengan melakukan pembayaran secara wajar untuk dijadikan sebagai dana kebajikan.

c. Ketentuan Penutup

1) Fatwa ini mulai berlaku pada tanggal ditetapkan, dengan ketentuan jika di kemudian hari ternyata terdapat kekeliruan, akan diperbaiki dan disempurnakan sebagaimana mestinya.

2) Agar setiap muslim dan pihakpihak yang memerlukan dapat mengetahuinya, semua pihak dihimbau untuk menyebarluaskan fatwa ini.

Nilai strategis yang ada pada MUI semakin terlihat dari salah satu komisi yaitu Komisi Fatwa yang concern memberikan fatwa untuk memberikan jawaban atau penjelasan ulama mengenai masalah keagamaan dan berlaku untuk umum. Namun apabila direlevansikan dengan fatwa - fatwa tentang zakat sejak tahun 1982-2011, dalam hal ini terdapat 10 fatwa MUI yang telah difatwakan, hal ini dapat digolongkan menjadi tiga bentuk yaitu:

1. Fatwa sumber-sumber zakat meliputi: Fatwa tentang zakat penghasilan (Fatwa MUI No 3 tahun 2003) dan fatwa tentang hukum zakat atas yang haram (Fatwa MUI No 13 tahun 2011).

2. Fatwa asnaf-asnaf zakat meliputi: Fatwa tentang amil zakat (Fatwa MUI No 8 tahun 2011) dan fatwa tentang pemberian zakat untuk beasiswa (Fatwa Nomor Kep-120/ MUI/ II/ 1996).

3. Fatwa pengelolaan zakat: Fatwa tentang intensifikasi pelaksanaan zakat (Fatwa tahun 1982), fatwa mentasharruf dana zakat untuk kegiatan produktif dan kemaslahatan umum (Fatwa tahun 1982), fatwa penggunaan zakat untuk istismar/investasi (Fatwa Nomor 4 tahun 2003), fatwa MUI tentang masalah zakat kontemporer meliputi defenisi, tugas, dan fungsi, kewajiban, dan hak-hak amil, zakat perusahaan, dan sebagainya (Keputusan Komisi B1 Ijtima' Ulama Komisi Fatwa MUI se-Indonesia III tentang Masail Fighiyyah Mu'ashirah [Masalah Fikih Kontemporer]), fatwa penarikan, pemeliharaan, dan penyaluran harta zakat (Fatwa Nomor 14 tahun 2011), dan fatwa penyaluran harta zakat bentuk asset kelolaan (Fatwa Nomor 15 tahun 2011).

Ketiga bentuk fatwa ini difatwakan karena adanya permintaan, pertanyaan dari masyarakat dan pemerintah serta responsif MUI sendiri (Amin, et.al, 2011: 890 - 894)

Fatwa MUI tentang masalah zakat sangat membantu umat dalam menghadapi persoalan seputar zakat, 
dimana dengan perkembangan zaman cenderung timbul persoalan-persoalan di tengah umat berkaitan dengan zakat. Untuk itu diharapkan kepada MUI untuk lebih sensitif terhadap persoalan yang muncul agar tidak terjadi praktik-praktik zakat di luar ketentuan syariah.

\section{PENUTUP}

\section{Kesimpulan}

Fatwa MUI tentang masalah zakat sangat membantu umat dalam menjalankan ibadah zakat sesuai dengan syariat. Hasil penelitian menunjukkan bahwa dari tahun 1982 s.d. 2011 ada 10 fatwa seputar zakat, di antaranya tahun 1982 ada 2 fatwa, tahun 1996 ada 1 fatwa, tahun 2003 ada 2 fatwa, tahun 2009 ada 1 fatwa, dan tahun 2011 ada 4 fatwa seputar zakat.

\section{Saran}

Kepada MUI agar senantiasa menelaah persoalan kontemporer tentang zakat, sehingga menjadi solusi di tengah masyarakat.

\section{DAFTAR KEPUSTAKAAN}

Abdul Aziz Dahlan (Eds). 1999. Ensiklopedi Hukum Islam I. Jakarta: PT Ichtiar Baru Van Hoeve.

Abdurrahman, Asjmuni. 2004. Manhaj Tarjih Muhammadiyah: Metodologi dan Aplikasi, Cetakan III, Yogyakarta: Pustaka Pelajar

Al-Zuhayly, Wahbah. 1995. Zakat Kajian Berbagai Mazhab. Judul Asli: “Al-Fiqh Al-islami wa"adillatuh". diterjemahkan oleh Agus Efendi dan
Bahruddin Fannany. Penerbit Asli: Dar al-Fikr, Damaskus. Bandung: PT. Remaja Rosdakarya.

Ambary, Hasan Muarif, dkk. 1999. Ensiklopedi Islam. Jakarta: PT Ichtiar Baru Van Hueve, jilid 5.

Amin, Makruf, et.al, 2011. Himpunan Fatwa MUI Sejak 1975, Jakarta: Erlangga.

Amirudin, Zen. 2009. Ushul Fiqih. Teras: Yogyakarta.

Anonim, t.th. Mengenal Istilah dan Rumus Fuqaha, Kediri, Pustaka De-Aly

Anshori, Abdul Ghofur. 2006. Hukum dan Pemberdayaan Zakat: Upaya Sinergis Wajib Pajak di Indonesia. Yogyakarta: Pilar Media (ANGGOTA IKAPI).

Depdikbud.1990. Kamus Besar Bahasa Indonesia. Jakarta: Balai Pustaka.

Echols, John M, Hasan Shadily. 2001. Ensiklopedi Islam. Jakarta: PT Ichtiar Baru Van Hoeve.

Febriansyah, M. Raihan, 2013. Muhammadiyah: 100 Tahun Menyinari Negeri, Yogyakarta: Majelis Pustaka dan Informasi Pimpinan Pusat Muhammadiyah

Hafidhuddin, Didin. 2002. Zakat dalam Perekonomian Modern. Jakarta: Gema Insani.

http://mui.or.id

Jamal, Mulyono dan Aziz, Muhammad Abdul Abdul Aziz, Metodologi Istinbath Muhammadiyah dan NU: (Kajian Perbandingan Majelis Tarjih dan Lajnah Bahtsul Masail), IJTIHAD: Jurnal Hukum dan Ekonomi Islam, ISSN: 1907-4514, Volume 7 Nomor 2, 
Sya'ban 1434/2013, tersedia http://www.ejournal.unida.gontor.a c.id

Lajnah Ta'lif Wan Nasyr NU Jawa Timur, 2007. Ahkamu al-Fuqaha; Solusi Problematika Aktual Hukum IslamKeputusan Muktamar, Munas, dan Konbes Nahdlatul Ulama (1926-2004), Cetakan III, Surabaya: Khalista.

Ma'luf, Luis, Al-Munjid fi Luhah wal Adab wal Ulum, Beirut, AlMaktabah al-Katulikiyah.

Kamali, Mohammad Hasyim. 1996. Kebebasan Berpendapat Dalam Islam. Bandung: Mizan.

Mubarak, Jaih. 2005. Ijtihad Kemanusiaan. Bandung: Pustaka Bani Quraisy.

Qardhawi, Yusuf. 2002. Figh Zakat, edisi Indonesia Hukum Zakat. diterjemahkan oleh Salman Harun, Didin Hafidhuddin dan Hasanuddin, Jakarta: PT. Pustaka
Litera Antar Nusa dan Badan Amil Zakat dan Infak/ Shodaqoh DKI Jakarta.

Salam, Abi Ubaid al-Qasim. 1982. Alamwal. Beirut: Dar al-Khatab alIlmiyah.

Sam, M. Ichwan, et.al, Himpunan Fatwa Zakat MUI Kompilasi Fatwa MUI tentang Masalah Zakat Tahun 1982 2011 (Jakarta : BAZNAS, 2011)

Suara Muhammadiyah No. 6 / 1355 (1936) hal 145.

Sudarsono. 1990. Kamus Hukum. Jakarta: PT Rineka Cipta.

Syahputra, Akmaluddin. t.th. Butir-Butir Pemikiran Islam Prof. Dr. H. Abdullah Syah MA. Bandung; Cipta Pustaka Media. 